\title{
A Review of Photocatalytic Treatment for Various Air Pollutants
}

\author{
P. Venkata Laxma Reddy, Ki-Hyun Kim* and Yong-Hyun Kim \\ Department of Environment and Energy, Sejong University, 98 Gun Ja Dong, Gwang Jin Gu, Seoul 143-747, Korea \\ *Corresponding author. Tel: +82-2-499-9151, E-mail: khkim@sejong.ac.kr
}

\begin{abstract}
Photocatalysis is a photochemical catalytic reaction which is a highly promising tool for the environmental cleanup process. It is very effective in treatment of environmental pollutants by its unique redox property. It has wide applications in the treatment of atmospheric pollutants (e.g., nitrogen dioxide, trichloroethylene, volatile organics, hydrogen sulfide, benzene, etc) through oxidative removal and by disinfection (aeromicro flora). In this research, the fundamental aspects of photocatalysis are described with respect to the composition of catalysts, experimental conditions (e.g., temperature, duration, etc), and interfering factors (e.g., catalyst deactivation).
\end{abstract}

Key words: Treatment of air, Pollution control, Photocatalysis, Oxidation of air pollutants

\section{INTRODUCTION}

Photocatalysis is a rapidly expanding technology for the treatment of air pollutants. It can be defined as the mechanism leading to "acceleration of photoreaction with the aid of a catalyst". The initial recognition on the heterogeneous photocatalysis was made when Fujishima and his colleagues discovered photolysis of water (Fujishima et al., 1972). In recent years, the use of semiconductor materials gained interests as photocatalytic medium for the removal of organic and inorganic species. This method has been suggested as a potent tool for environmental protection due to its great oxidation capacity (Robert and Malato, 2002). The photocatalysis is a very effective tool to process the environmental pollution. However, its application toward the treatment of the air pollutants is open widely. Hence, in this article, emphasis is given to describe its treatment efficiency in a number of aspects by surveying the uptodated knowledge in this field of research.

The catalyst can be used to induce oxidation and re- duction of substrates simultaneously. UV light with higher energy band of $<390 \mathrm{~nm}$ (or sunlight 390-700 $\mathrm{nm}$ ) can be used as excitation energy. Heterogeneous photocatalysis using semiconductors (such as titanium dioxide $\left(\mathrm{TiO}_{2}\right)$ ) can be more effective than conventional waste treatment methods for removing organic species in the environment. The redox capacity of such media promotes the conversion of substrate to carbondioxide and water. This process is also called mineralization. Carbon dioxide is formed as the end product due to the oxidation of carbon atom of the reactant molecule. However, depending on the composition of reactant, the end product of the reaction can differ to a degree (Denny et al., 2007).

Photocatalysis with a semiconductor oxide (such as $\mathrm{TiO}_{2}$ ) is initiated by the absorption of a photon with energy equivalent to or greater than the band gap of the semiconductor (c.a. $3.2 \mathrm{eV}$ for anatase). It then produces electrons and holes $(\mathrm{e}-/ \mathrm{h}+)$ in conduction band and valence band, respectively (Wilke and Breuer, 1999). Following the irradiation, the $\mathrm{TiO}_{2}$ particle can act either as an electron donor or acceptor for molecules in the surrounding medium. The electron and hole can also be recombined to release the absorbed light energy in the form of heat. When this recombination takes place, $\mathrm{TiO}_{2}$ cannot act as catalyst. Under such circumstances, both the redox process cannot take place. The valence band hole is strongly oxidizing due to the presence of $\mathrm{OH}$ radical, while the conduction band electron is strongly reducing due to the presence of $\mathrm{O}_{2}{ }^{-}$radical (Bahruji et al., 2010).

At the external surface, the excited electron on the conduction band and the hole on the valence band can take part in redox reactions. As the electron is excited from valence band to conduction band by absorption of energy, an empty positive hole is formed at valence band. When $\mathrm{TiO}_{2}$ comes in contact with water, the hydroxylation of hole takes place to form hydroxyl radical. The $\mathrm{OH}^{-}$radical adsorbed on valence band is anion form. As it has negative electrical charge, it is strongly attracted to positive hole. After being combined with hole, its negative charge is neutralized to form 
hydroxyl radical $\left({ }^{\circ} \mathrm{OH}\right)$. This neutralized hydroxyl radical is very reactive in nature with strong affinity for electrons which facilitates the oxidation of other compounds. This hydroxyl radical (2.08) is the strongest oxidizing agent only after fluorine (3.06) (Datta et al., 2004).

The oxidation reactions are hence observed due to the presence of hydroxyl radical at valence band as well as other oxidizing agents, which are present in solution of reactants. An important reaction of the conduction band electron is the reduction of the adsorbed $\mathrm{O}_{2}$ to $\mathrm{O}_{2}{ }^{-}$. Thus, a redox environment is created by the presence of hydroxyl (oxidizing) and superoxide (reducing) radical over $\mathrm{TiO}_{2}$ surface. Upon the creation of the redox environment, the mineralization of desired component is observed, i.e., conversion of initial compound to final end product which is mainly carbondioxide, water, and organic acids (Liu et al., 2006) (Latasree et al., 2004).

\section{1 Characteristics of an Ideal Photocatalyst, Advantages of This Method}

According to Fujishima et al. (2000), the ideal photocatalyst should possess the following properties.

(a) Photo activity, low cost, and non-toxic nature: For large scale environmental clean up operations, the photocatalyst has to be available at low cost without toxic properties to flora and fauna when used at large concentrations.

(b) Biological and chemical inertness: The catalyst used in the process of substrate treatment must not promote the formation of other complex and undesired substrates.

(c) Stability towards photocorrosion: The catalyst must not undergo corrosion under prolonged light exposure; it has to be stable to tolerate the long light exposure which will be persistent throughout the process.

(d) Suitability towards visible or near UV light: An excitation source which is essential for the initiation of reaction must be of low energy in the visible of near UV region so that the high radiation energy is not required.

\section{2 Various Steps in Photocatalysis Process}

Heterogeneous photocatalysis is type of interaction where the reactant and catalyst exist in different phases. This type of reaction generally involves the following five steps (Shan et al., 2010): (i) diffusion of reactants to the surface of catalyst, (ii) adsorption of reactants onto the surface, (iii) reaction on the surface, (iv) desorption of products from the surface, and (v) diffusion of products from the surface (Devilliers, 2006) (Fig. 1).

\section{PHOTOCATALYTIC MATERIALS}

A wide range of semiconductors may be used for photocatalysis such as $\mathrm{TiO}_{2}, \mathrm{ZnO}, \mathrm{SnO}_{2}, \mathrm{WO}_{3}, \mathrm{Fe}_{2} \mathrm{O}_{3}$, and CdS (Vinu and Madras, 2010). Among these semiconductor oxides, $\mathrm{ZnO}$ is generally unstable in illuminated conditions, especially at low $\mathrm{pH}$ values. $\mathrm{WO}_{3}$, although useful in the visible range, is less active photocatalytically than $\mathrm{TiO}_{2}$. Among others, the possibilities of $\mathrm{CdS}, \mathrm{ZnS}$, and iron oxides have been also tested. However, all of those materials have suffered from corrosive properties. Hence, $\mathrm{TiO}_{2}$ is yet the most useful material for photocatalytic purposes, owing to a number of advantages: exceptional optical and electronic properties, chemical stability, non-toxicity and low

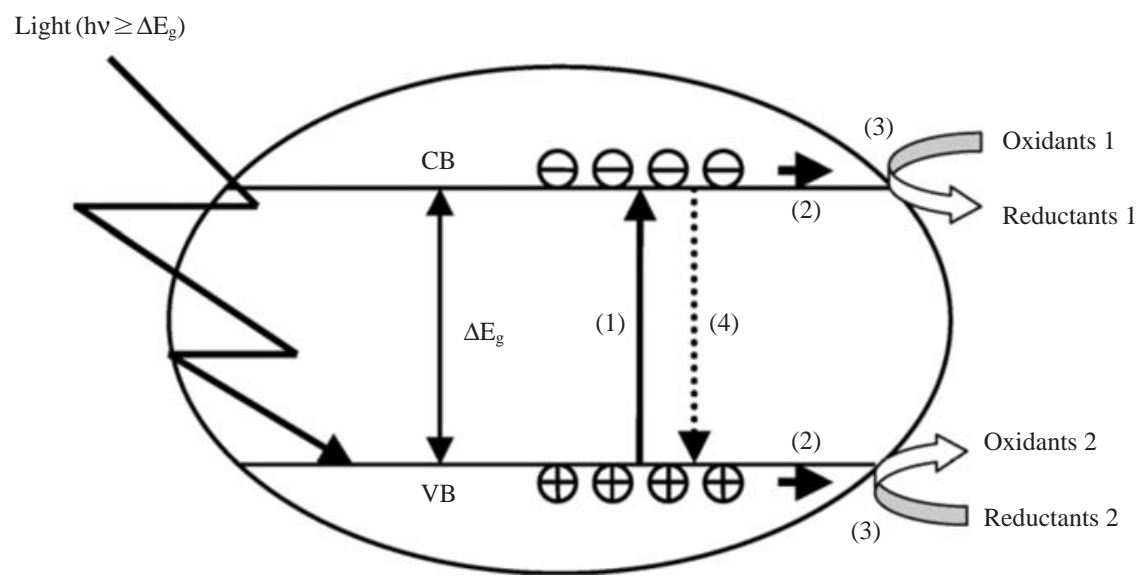

Fig. 1. Diagrammatic representation of Photocatalysis mechanism (Demeestere et al., 2007). 
cost (Litter, 1999) (Fig. 2).

The commonest crystalline forms of $\mathrm{TiO}_{2}$ are anatase and rutile. The third form is brookite. Whose form is uncommon and unstable (It is stable only at high temperature). The structures of anatase, rutile, and brookite are presented in Fig. 3. However, the usage of $\mathrm{TiO}_{2}$ as a photocatalyst can also be limited by several factors.

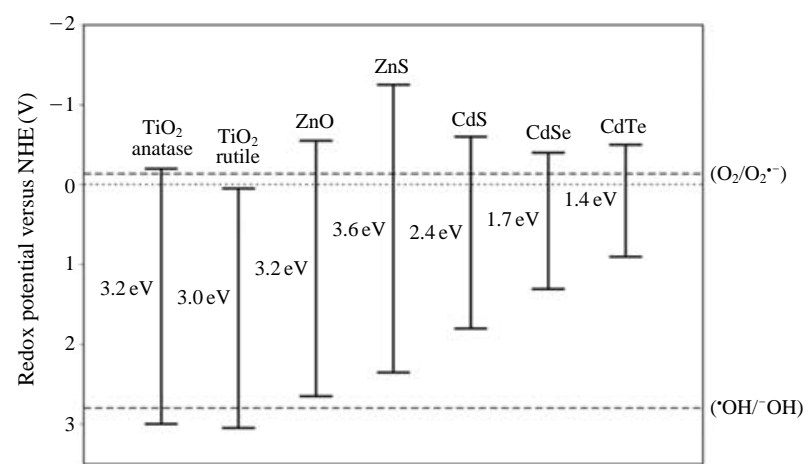

Fig. 2. Band gaps of various semiconductor oxides (Demeestere et al., 2007).

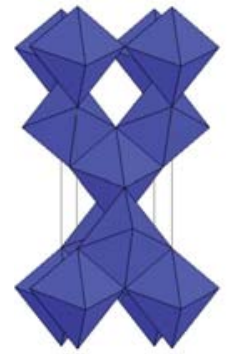

Anatase

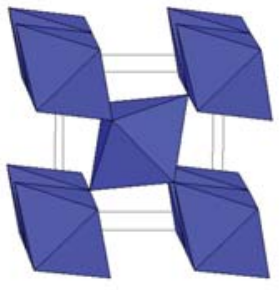

Rutile

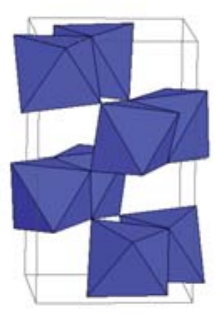

Brookite
The most restrictive factor has been the need of UV (wavelength of $<387 \mathrm{~nm}$ ) as an excitation source due to its wide band gap $(3.2 \mathrm{eV})$. Only 5 percent of visible radiation is available for this required excitation energy (Fig. 4). The photocatalytic method has wide applications in the waste water treatment, due to high availability of $\mathrm{OH}$ in water (Blanco et al., 2009). Although different in nature, its application to the treatment of various range of air pollutants is also reported. The catalyzing, deodorizing, adsorbing, and disinfection property of the $\mathrm{TiO}_{2}$ makes it a potential photocatalyst for the treatment of air pollutants.

Intensive studies are in progress to develop the existing materials or to prepare alternate materials for improved photocatalytic behaviour, which can be used under solar energy. To this end, the absorption of radiation must be shifted from UV to visible light region; it is active in UV region and is usually doped with a metal to structurally modify and increase the absorption capacity in the visible region. Visible light is renewable source with high potential, when employed at large scale treatment operations. The other demanding research area includes the modifications to increase the surface area of catalyst. The greater the surface area of the catalyst, the higher the extent of interaction takes place between the catalyst and reactant (Machado and charles, 2006). As a result, a greater efficiency in reaction can be acheived. Several studies reported that doping $\mathrm{TiO}_{2}$ with anions (such as carbon, nitrogen, sulfur, boron, and fluorine) can help shift the optical absorption edge of $\mathrm{TiO}_{2}$ towards lower energy ( $\mathrm{Li}$ et al., 2005). Through such modification, one may increase the photocatalytic activity in visible light region. By the process of doping, the gap between valence and conduction band can be reduced with the formation of interbands between them (Juanru et al., 2007). Hence, less

Fig. 3. Different phases of $\mathrm{TiO}_{2}$ (Smyth, 2010).

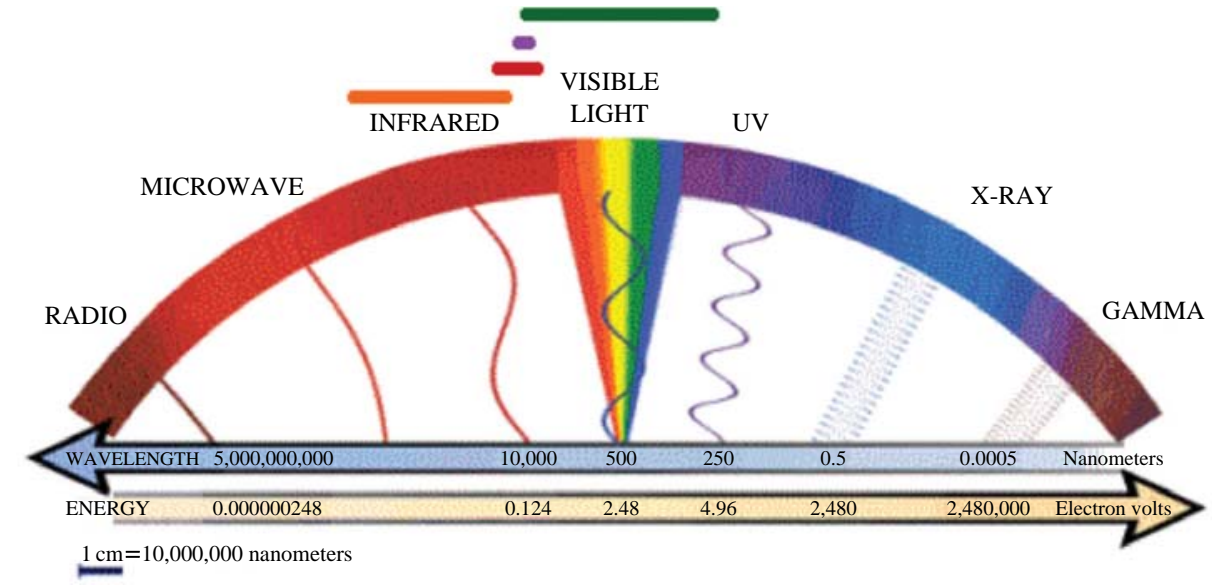

Fig. 4. Electromagnetic spectrum showing visible and UV region (www.spacetoday.org). 
energy source (like visible radiation) can be sufficient for the excitation of electron from valence band to conduction band.

\section{PHOTOCATALYSIS AND ITS APPLICATION TO THE TREATMENT OF AIR POLLUTANTS}

Photocatalysis can be used as a very effective tool to treat air pollutants. It is also proved that this process is applicable in ambient environments, especially less humidified indoor environments (Jo and Kim, 2009). It has various advantages in comparison to the other conventional methods (Table 1). It has also been proven to deal with a wide range of air pollutants (Table 2). Here some pollutants and their treatment efficiency are taken as a reference to indicate its efficiency against different types pollutants released from various sources.

\subsection{Purification of Indoor Air and Gaseous Effluents}

There are various indoor pollutants which can be responsible to cause various chronic health problems. Radons, formaldehyde, and VOC are common examples of indoor air pollutants. The number of aromatic VOC including benzene, toluene, and xylene (commonly called BTX) has been treated by the photocatalytic method (Pichat et al., 2000). The $\mathrm{TiO}_{2}$ photocatalytic treatment of toluene is known to yield benzaldehyde, with high applications in synthetic industry (Sleiman et al., 2009). $\mathrm{TiO}_{2}$ also has high capacity to deodorize the indoor air. The deodorization may be considered as the outcome of oxidation of the pollutant (Wei et al., 2010). A photo-reactor coated with $\mathrm{TiO}_{2}$ fiber glass mesh in the presence of artificial radiation light at approximately $365 \mathrm{~nm}$ (UV) is found to be very efficient in the mineralization of BTX compounds (Pichat et al., 2000). This oxidation can be further enhanced under the presence of strong oxidants (like ozone) in the in-

Table 1. Comparison of various treatment methods for airborne pollutants.

\begin{tabular}{lll}
\hline \multicolumn{1}{c}{ Treatment methods } & \multicolumn{1}{c}{ Advantages } & \multicolumn{1}{c}{ Disadvantages } \\
\hline Biological treatment & Efficient in treatment of pollutants, with low cost & Very slow and needs large area \\
\hline Photocatalysis & $\begin{array}{l}\text { Stable, cheap, reusable } \\
\text { high activity, chemically and biologically inert, } \\
\text { works at ambient environment }\end{array}$ & External source is required \\
\hline Electrostatic seperation & Treats particle matter than gaseous pollutants & High cost, can treat only dry emission \\
\hline Ozonation & $\begin{array}{l}\text { Efficiency in treatment of recalcitrants and also } \\
\text { disinfection of air can be done }\end{array}$ & $\begin{array}{l}\text { Increased ozone in air causes problems, } \\
\text { Formation of ozonated pollutants }\end{array}$ \\
\hline Photolysis & Very fast removal & Highly harmful because of high UV radiation \\
\hline Adsorption & $\begin{array}{l}\text { Very useful with volatile compounds } \\
\text { Hazardous compounds and unreactive compounds } \\
\text { can be observed }\end{array}$ & $\begin{array}{l}\text { Most of adsorbents are specific, } \\
\text { Disposal of adsorbents is serious problem }\end{array}$ \\
\hline
\end{tabular}

Table 2. Examples of photocatalytic treatment for the treatment of air pollutants.

\begin{tabular}{|c|c|c|c|}
\hline Catalyst employed & Target compound & Catalyst and reaction features & References \\
\hline $\begin{array}{l}\mathrm{TiO}_{2} \\
\mathrm{Ti} / \mathrm{SiO}_{2}\end{array}$ & BTX & $\begin{array}{l}\text { Very efficient in treatment } \\
\text { adsorbing as well as catalytic agent }\end{array}$ & $\begin{array}{l}\text { (Pichat et al., 2000) } \\
\text { (Zou et al., 2006) }\end{array}$ \\
\hline $\begin{array}{l}\mathrm{TiO}_{2} \\
\mathrm{TiO}_{2} \text { on } \mathrm{Si} \text { support }\end{array}$ & TCE & $\begin{array}{l}\text { DCAC (dichloroacetyl chloride) and various other products } \\
\text { DCAC is not formed, others are formed as } \mathrm{TiO}_{2}\end{array}$ & $\begin{array}{l}\text { (Wang et al., 2002) } \\
\text { (Park et al., 2004) }\end{array}$ \\
\hline $\mathrm{Cu} / \mathrm{TiO}_{2}$ & $\mathrm{NO}_{2}$ & Efficiency decreased by accumulation of $\mathrm{HNO}_{3}$ & (Ohko et al., 2009) \\
\hline $\begin{array}{l}\mathrm{Cr}-\mathrm{MCM}-\mathrm{TiO}_{2} \\
\mathrm{CdS}\end{array}$ & $\mathrm{H}_{2} \mathrm{~S}$ & $\begin{array}{l}\mathrm{SO}_{2} \text { is not formed, but sulphates are formed } \\
\text { Hydrogen production and efficiency }\end{array}$ & $\begin{array}{l}\text { (Portela et al., 2008) } \\
\text { (Bai et al., 2010) }\end{array}$ \\
\hline $\begin{array}{l}\mathrm{TiO}_{2} \\
\mathrm{Pd}-\mathrm{TiO}_{2}\end{array}$ & Gaseous benzene & $\begin{array}{l}\text { Good efficiency in mineralization } \\
2.32 \text { higher activity than } \mathrm{TiO}_{2}\end{array}$ & $\begin{array}{l}\text { (Zhong et al., 2007) } \\
\text { (Zhong et al., 2009) }\end{array}$ \\
\hline $\mathrm{TiO}_{2}$ & Chloramines & Chlorobenzene and phenols are formed & (An et al., 2011) \\
\hline $\mathrm{Ag}-\mathrm{TiO}_{2}$ & Disinfection & $\begin{array}{l}\text { Effective in disinfection of B. aereus, E. coli, S. auerus, } \\
\text { A. niger }\end{array}$ & (Vohra et al., 2006) \\
\hline
\end{tabular}


door environmental conditions. Doping of $\mathrm{TiO}_{2}$ can further increase its catalytic efficiency (Park et al., 2004). VOCs in urban atmosphere are produced mainly by automobile exhausts. The majority of them are very stable recalcitrant compounds. $\mathrm{TiO}_{2}-\mathrm{SiO}_{2}$ based photocatalysis was thus employed for the removal of VOC (Zou et al., 2006). The catalyst can act as adsorbing as well as catalyzing agent. The amounts of hydrocarbons and carbondioxide are observed as the end products by such photocatalytic treatment of VOC. The presence of NO (along with VOC) showed some interfering effects (Ao et al., 2003). In addition, it is also reported that humidity as well reactive nature of $\mathrm{NO}$ with VOCs had huge influence on the progress of reaction.

\section{2 Removal of Trichloroethylene (TCE)}

TCE is a very harmful widespread gaseous air pollutant, being carcinogenic in nature. When gas phase TCE is subjected to photodegradation in packed bed continuous flow reactor, it yielded many intermediate products like phosgene, dichloroacetyl chloride (DCAC), chloroform, hexachloroethane, alcohols, esters, aldehydes, carbon monoxide, and carbon dioxide (Wang et al., 2002). Phosgene emission can be reduced by using allopane clay suspended $\mathrm{TiO}_{2}$. Here, phosgene is adsorbed on to surface of allopane clay catalyst, and it can be degraded gradually (Nishikiori et al., 2011). TCE degradation mechanisms usually begin with the $\mathrm{Cl}^{-}$subtraction by the attack of hydroxyl radical of water present in air (Amama et al., 2001). TCE has also been removed by employing degussa titania coated reactor wall deposited on silica based support (Mohseni, 2005). A large amount of TCE can be removed by this process. The removal efficiency of TCE is very high due to the addition of silica support on degussa, as it provides higher interactive surface area for catalyst and reactant. The intermediates formed in the presence of silica-based support and in its absence can exhibit huge variations. Pure degussa titania interaction with TCE resulted in phosgene and dichloro acetyl chloride (DCAC) as end product (Mohseni, 2005). However, in the presence of silica based support, the DCAC was not formed. Instead, a very little amounts of carbon tetrachloride and chloroform were formed. As such, the efficiency of TCE photodegradation is very high, when $\mathrm{TiO}_{2}$ is doped with high valency cations (Park et al., 2004).

\section{3 Photocatalytic Reduction of $\mathrm{NO}_{2}$}

$\mathrm{NO}_{2}$ is harmful and reactive compound and is emitted from various industrial sources (Latza et al., 2009). For removal of $\mathrm{NO}_{2}$, its photocatalytic reduction to NO by cuppric ion loaded thin $\mathrm{TiO}_{2}$ films was studied
(Ohko et al., 2009). As cupric ion can induce photocatalytic reduction of $\mathrm{NO}_{2}$ to $\mathrm{NO}$ in air, it can also act as oxidizing agent to yield $\mathrm{HNO}_{3}$ from NO. As such, cuppric ion can be used to provide delicate redox conditions. However, oxidation efficiency of $\mathrm{NO}$ to $\mathrm{HNO}_{3}$ decreased, as the accumulation of $\mathrm{HNO}_{3}$ proceeds. In an alternative method, the photocatalytic oxidation of NO can take place under some specified hydrothermal conditions. The P25 degussa titania, commercially produced by a German company (Anatase and Rutile in ratio of $3: 1$ ), showed best oxidation of $\mathrm{NO}$, if the catalyst is calcined at temperature of 200 degree for the duration of $24 \mathrm{hrs}$ (Wu et al., 2008). The application of photocatalytic concrete material in urban places has also been very effective in the treatment of $\mathrm{NO}_{2}$ at highly polluted urban areas (Ballari et al., 2010).

\section{3. $4 \mathrm{H}_{2} \mathrm{~S}$ Photo Degradation}

Hydrogen sulphide is a colorless, poisonous, flammable gas with the characteristic foul odor of rotten egg (Kourtidis et al., 2008; Lambert et al., 2006). It often results from the bacterial breakdown of organic matter in the absence of oxygen, such as in swamps and sewers (anaerobic digestion) (Chaiprapat et al., 2011). It also occurs in volcanic gases, natural gas, and some well waters. $\mathrm{H}_{2} \mathrm{~S}$ can also be subject to photodegradation by chromium doped molecular seives in the presence of $\mathrm{TiO}_{2}$ (Portela et al., 2008). The chromium doped mesoporous crystalline molecular (Cr-MCM) sieves, prepared by hydrothermal method, are impregnated with $\mathrm{TiO}_{2}$. During the photodegradation, there was no oxidation of $\mathrm{H}_{2} \mathrm{~S}$ to sulfurdioxide. However, the accumulation of sulphates deactivated the catalytic property of chromium. As another approach of $\mathrm{H}_{2} \mathrm{~S}$ treatment, its photocatalytic decomposition was carried out in the presence of CdS catalyst. It allows the decomposition and photodegradation simultaneously with the production of $\mathrm{H}_{2}$ (Bai et al., 2010).

\subsection{Oxidation of Gaseous Benzene}

Benzene is a flammable, colorless and carcinogenic compound (Bird et al., 2005). It is naturally produced, when wood is completely burned (during forest fires) or volcanic eruptions (Capaccioni et al., 2004). The commenest exposure to benzene is through the inhalation of cigarette smoke or car exhaust (Edwards and Jhantunen, 2001) (Weisel, 2010). This extremely toxic compound was discovered in the gas emitted by burning coal (The Lancet, 1904).

The photocatalytic oxidation of benzene can be carried out utilization of doped $\mathrm{TiO}_{2}$ catalysts (Zhong et al., 2007; Fu et al., 1995). The doped catalyst exhibited high decomposition of benzene than bare $\mathrm{TiO}_{2}$. It is highly reactive in the presence of sunlight, indica- 
tive of high potential in solar photocatalysis. The addition of $\mathrm{Pd}$ in to $\mathrm{TiO}_{2}$ increases photocatalytic activity by more than 2.3 times than pure $\mathrm{TiO}_{2}$ (Zhong et al., 2009).

\section{6 Photo Degradation and Detoxification of Chloranilines}

Choloroaniline is a typical semi-volatile aromatic amine (Kataoka, 1996). It is precursor for various antibacterial products. It is strong irritant with the potential for tissue damage. The photocatalytic degradation of chloramines containing gases can be achieved very rapidly by $\mathrm{TiO}_{2}$ catalyst (An et al., 2011). Cholorobenzene and phenols are formed as intermediates of this degradation. Here the degradation as well as detoxification of the gaseous aromatic amines is simultaneously observed by this method.

\section{7 Microbial Disinfection in Air by Photocatalysis}

Air usually contains high amount of micro-organisms. There are various airborne diseases which are transmitted through air (like tuberculosis, whooping cough, etc) (Martinez et al., 2008). The application of photocatalysis for the disinfection of microbes has been exercised. The $\mathrm{Ag}$ doped $\mathrm{TiO}_{2}$ acts as a very good disinfecting agent (Akhavan, 2009). The catalyst coated filters when passed over recirculation air, can induce disinfection of various microorganisms (e.g., Bacillus cereus, Staphylococcus aureus, Escherichia coli, and Aspergillus niger) which are used as indices for disinfecting property (Vohra et al., 2006). Photocatalysis is also very efficient in the inactivation of microbial growth. The principle of disinfection of photocatalyst can be expressed as the disintegration of cells by the activity of $\mathrm{OH}$ radical which oxidizes the intracellular components of micro-organisms (Cheng et al., 2007). Thus, this method can be very beneficial under rapidly infectious conditions.

\section{CONCLUSIONS}

This article is written to review basic principle and concept of photocatalysis and its application toward the treatment of air pollutants. A wide variety of air pollutants and photocatalytic methods that have been successful in their treatment was briefly described here. Although the application of photocatalysis was has been extended to cover many field conditions, the progress in this field of research is yet insufficient. However, based on the realization of its potential, a lot of photocatalytic applications and material modifications have been made for pollution control on a large scale. Yet a vast variety of atmospheric gases are not subjected to this method of treatment. In the near future, one needs to find a more favorable means to extend its applicability for the abatement of various air pollutants.

\section{ACKNOWLEDGEMENTS}

This work was supported by a National Research Foundation of Korea (NRF) grant funded by the Ministry of Education, Science and Technology (MEST) (No. 2010-0007876).

\section{REFERENCES}

Akhavan, O. (2009) Lasting antibacterial activities of Ag$\mathrm{TiO}_{2} / \mathrm{Ag} / \mathrm{a}-\mathrm{TiO}_{2}$ nanocomposite thin film photocatalysts under solar light irradiation. Journal of Colloid and Interface Science 336, 117-124.

Amama, P.-B., Itoh, K., Murabayashi, M. (2001) Photocatalytic oxidation of trichloroethylene in humidified atmosphere. Journal of Molecular Catalysis A: Chemical 176, 165-172.

An, T., Sun, L., Li, G., Gao, Y., Ying, G. (2011) Photocatalytic degradation and detoxification of o-chloroaniline in the gas phase: Mechanistic consideration and mutagenicity assessment of its decomposed gaseous intermediate mixture. Applied Catalysis B: Environmental 102, 140-146.

Ao, C.-H., Lee, S.-C., Mak, C.-L., Chan, L.-Y. (2003) Photodegradation of volatile organic compounds (VOCs) and $\mathrm{NO}$ for indoor air purification using $\mathrm{TiO}_{2}$ : promotion versus inhibition effect of NO. Applied Catalysis B: Environmental 42, 119-129.

Bahruji, H., Bowker, M., Dickinson, A., Greaves, J., James, D., Millard, L., Pedrono, F. (2010) Sustainable $\mathrm{H}_{2}$ gas production by photocatalysis. Journal of Photochemistry and Photobiology A: Chemistry 216, 115-118.

Bai, X.-F., Cao, Y., Wu, W. (2010) Photocatalytic decomposition of $\mathrm{H}_{2} \mathrm{~S}$ to produce Hydrogen over CdS nanoparticles formed in HY-zeolite pore. Renewable Energy (Article in Press).

Ballari, M.-M., Yu, Q.-L., Brouwers, H.-G. (2010) Experimental study of the $\mathrm{NO}$ and $\mathrm{NO}_{2}$ degradation by photocatalytically active concrete. Catalysis Today 161, 165180.

Bird, M.-G., Greim, H., Snyder, R., Rice, J.-M. (2005) International symposium: Recent advances in benzene toxicity. Chemico-Biological Interactions 153-154, 15.

Blanco, J., Malato, S., Alarcón, D., Gernjak, W., Maldonado, M.-I. (2009). Review of feasible solar energy applications to water processes. Renewable and Sustainable Energy Reviews 13, 1437-1445.

Capaccioni, B., Taran, Y., Tassi, F., Vaselli, O., Mangani, 
G. (2004) Source conditions and degradation processes of light hydrocarbons in volcanic gases: an example from El Chichón volcano (Chiapas State, Mexico). Chemical Geology 206, 81-96.

Chaiprapat, S., Mardthing, R., Kantachote, D., Karnchanawong, S. (2011) Removal of hydrogen sulfide by complete aerobic oxidation in acidic biofiltration. Process Biochemistry 46, 344-352.

Cheng, Y.-W., Chan, R.-C.-Y., Wong, P.-K. (2007) Disinfection of Legionella pneumophila by photocatalytic oxidation. Water Research 41, 842-852.

Datta, C., Naidu, R., Yenkie, M.-K. (2004) Photo-oxidative degradation of synthetic organic pollutant $\mathrm{p}$-nitrophenol. Journal of Scientific and Industrial Research 63, 518-521.

Demeestere, K., Dewulf, J., Langenhove, H.-V. (2007) Heterogeneous photocatalysis as an advanced oxidation process for the abatement of chlorinated, monocyclic aromatic and sulfurous volatile organic compounds in air. Environmental Science and Technology 37, 489-538.

Denny, F., Scott, J., Chiang, K., Teoh, W.-Y., Amal, R. (2007) Insight towards the role of platinum in the photocatalytic mineralization of organic compounds. Journal of Molecular Catalysis A: Chemical 263, 93-102.

Devilliers, D. (2006) Semiconductor photocatalysis. Energia Centre for Applied Energy Research 17, 1-4.

Edwards, R.-D., Jantunen, M.-J. (2001) Benzene exposure in Helsinki, Finland. Atmospheric Environment 35, 1411-1420.

Fu, X., Zeltner, W.-A., Anderson, M.-A. (1995) The gasphase photocatalytic mineralization of benzene on porous titania-based catalysts. Applied Catalysis B: Environmental 6, 209-224.

Fujishima, A., Honda, K., Kikuchi, S. (1969) Photosensitized electrolytic oxidation on $\mathrm{TiO}_{2}$ semiconductor electrode. J Chem Soc Japan (Kogyo Kagaku Zasshi) 72, 108-109.

Fujishima, A., Rao, N.-T., Tryk, A. (2000) $\mathrm{TiO}_{2}$ photocatalysts and diamond electrodes. Electrochimica Acta 45, 4683-4690.

Jo, W.-K., Kim, J.-T. (2009) Application of visible-light photocatalysis with nitrogen-doped or unmodified titanium dioxide for control of indoor-level volatile organic compounds. Journal of Hazardous Materials 164, 360366.

Juanru, H., Mingwei, L., Zhong, C. (2007) Advances in doping of titania photocatalytic catalysts. Industrial Catalysis 15, 1-4.

Kataoka, H. (1996) Derivatization reactions for the determination of amines by gas chromatography. Journal of Chromatography 733, 19-34.

Kourtidis, K., Kelesis, A., Petrakakis, M. (2008) Hydrogen sulfide $\left(\mathrm{H}_{2} \mathrm{~S}\right)$ in urban ambient air. Atmospheric Environment $42,7476-7482$.

Lambert, T.-W., Goodwin, V.-M., Stefani, D., Strosher, L. (2006) Hydrogen sulfide $\left(\mathrm{H}_{2} \mathrm{~S}\right)$ and sour gas effects on the eye. Science of the Total Environment 367, 122.
Lathasree, S., Nageswara Rao, A., SivaSankar, B., Sadasivam, V., Rengaraj, K. (2004) Heterogeneous photocatalytic mineralisation of phenols in aqueous solutions. Journal of Molecular Catalysis A: Chemical 223, 101105.

Latza, U., Gerdes, S., Baur, X. (2009) Effects of nitrogen dioxide on human health: Systematic review of experimental and epidemiological studies conducted between 2002 and 2006. International Journal of Hygiene and Environmental Health 212, 271-287.

Li, Y., Hwang, D.-S., Lee, N.-H., Kim, S.-J. (2005) Synthesis and characterization of carbon-doped titania as an artificial solar light sensitive photocatalyst. Chemical Physics Letters 404, 25-29.

Litter, M-I. (1999) Heterogeneous photocatalysis: Transition metal ions in photocatalytic systems. Applied Catalysis B: Environmental 23, 89-114.

Liu, J.-H., Yang, R., Li, S.-M. (2006) Preparation and application of efficient $\mathrm{TiO}_{2} / \mathrm{ACF}$ s photocatalyst. Journal of Environmental Sciences 18, 979-982.

Machado, L.-C.-R., Charles, B. (2006) Floating photocatalysts based on $\mathrm{TiO}_{2}$ supported on high surface area exfoliated vermiculite for water decontamination. Catalysis Communications 7, 538-541.

Martinez, L., Blanc, L., Nunn, P., Raviglione, M. (2008) Tuberculosis and air travel: WHO guidance in the era of drug-resistant TB. Travel Medicine and Infectious Disease 6, 177-181.

Mohseni, M. (2005) Gas phase trichloroethylene (TCE) photooxidation and by product:photolysis vs. titania/ silica based photocatalysis. Chemosphere 59, 335-342.

Nishikiori, H., Furukawa, M., Fujii, T. (2011) Degradation of trichloroethylene using highly adsorptive allophane $\mathrm{TiO}_{2}$ nanocomposite. Applied Catalysis B: Environmental 102, 470-474.

Ohko, Y., Noguchi, H., Nakamura, Y., Negishi, N., Takeuch, K. (2009) Highly selective photocatalytic reduction of $\mathrm{NO}_{2}$ in air to $\mathrm{NO}$ using $\mathrm{Cu}^{2+}$-loaded $\mathrm{TiO}_{2}$ thin films. Journal of Photochemistry and Photobiology A: Chemistry 206, 27-31.

Park, S.-E., Joo, H., Kang, J.-W. (2004) Effect of impurities in $\mathrm{TiO}_{2}$ thin films on trichloroethylene conversion. Conversion of Solar Energy Materials and Solar Cells 83, 39-53.

Pichat, P., Disdier, J., Van, H.-C., Mas, D., Goutailler, G., Gaysse, C. (2000). Purification/deodorization of indoor air and gaseous effluents by $\mathrm{TiO}_{2}$ photocatalysis. Catalysis Today 63, 363-369.

Portela, R., Canela, M.-C., Sánchez, B., Marques, F.-C., Stumbo, A.-M., Tessinari, R.-F., Coronado, J.M., Suárez, S. (2008) $\mathrm{H}_{2} \mathrm{~S}$ photodegradation by $\mathrm{TiO}_{2} / \mathrm{M}-\mathrm{MCM}-$ $41(\mathrm{M}=\mathrm{Cr}$ or $\mathrm{Ce})$ : Deactivation and by-product generation under UV-A and visible light. Applied Catalysis B: Environmental 84, 643-650.

Robert, D., Malato, S. (2002). Solar photocatalysis: a clean process for water detoxification. The Science of the Total Environment 291, 85-97.

Shan, A.-Y., Mohd, T.-I., Rashid, S.-A. (2010) Immobili- 
sation of titanium dioxide onto supporting materials in heterogeneous photocatalysis: A review. Applied Catalysis A: General 389, 1-8.

Sleiman, M., Conchon, P., Ferronato, C., Chovelon, J.-M. (2009) Photocatalytic oxidation of toluene at indoor air levels (ppbv): Towards a better assessment of conversion, reaction intermediates and mineralization. Applied Catalysis B: Environmental 86, 159-165.

Smith, J. (2010). The $\mathrm{TiO}_{2}$ Group. University of Colorado. USA. (http://ruby.colorado.edu/ smyth/min/tio2.html)

The Lancet (1904) Benzene a poisonous content of coal gas.163, 526-527.

Vinu, R., Madras, G. (2010) Environmental remediation and photocatalysis. Journal of the Indian Institute of Science 90, 189-229.

Vohra, A., Goswami, D.-Y., Deshpande, D.-A., Block, S.-S. (2006) Enhanced photocatalytic disinfection of indoor air. Applied Catalysis B: Environmental 64, 57-65.

Wang, K.-H., Jehng, J.-M., Hsieh, Y.-H., Chang, C. (2002) The reaction pathway for the heterogeneous photocatalysis of trichloroethylene in gas phase. Journal of Hazardous Materials 90, 63-75.

Wei, Z., Sun, J., Xie, Z., Liang, M., Chen, S. (2010) Removal of gaseous toluene by the combination of photocatalytic oxidation under complex light irradiation of UV and visible light and biological process. Journal of Hazardous Materials 177, 814-821.

Weisel, C.-P. (2010) Benzene exposure: An overview of monitoring methods and their findings. Chemico-Bio- logical Interactions 184, 58-66.

Wilke, K., Breuer, H.-D. (1999) The influence of transition metal doping on the physical and photocatalytic properties of titania. Journal of Photochemistry and Photobiology A: Chemistry 121, 49-53.

Wu, Z., Wang, H., Liu, Y., Gu, Z. (2008) Photocatalytic oxidation of nitric oxide with immobilized titanium dioxide films synthesized by hydrothermal method. Journal of Hazardous Materials 151, 17-25.

www.spacetoday.org/DeepSpace/Telescopes/GreatObserv atories/Chandra/ChandraSpectrum.htm.

Zhong, J., Lu, Y., Jiang, W.-D., Meng, Q-M., He, X.-Z., Li, J.-Z., Chen, Y.-Q. (2009) Characterization and photocatalytic property of $\mathrm{Pd} / \mathrm{TiO}_{2}$ with the oxidation of gaseous benzene. Journal of Hazardous Materials 168, 1632-1635.

Zhong, J., Wang, J., Tao, L., Gong, M., Zhimin, L., Chen, L. (2007) Photocatalytic degradation of gaseous benzene over $\mathrm{TiO}_{2} / \mathrm{Sr}_{2} \mathrm{CeO}_{4}$ : Preparation and photocatalytic behavior of $\mathrm{TiO}_{2} / \mathrm{Sr}_{2} \mathrm{CeO}_{4}$. Journal of Hazardous Materials 140, 200-204.

Zou, L., Luo, Y., Hooper, M., Hu, E. (2006) Removal of VOCs by photocatalysis process using adsorption enhanced $\mathrm{TiO}_{2}-\mathrm{SiO}_{2}$ catalyst. Chemical Engineering and Processing 45, 959-964.

(Received 1 March 2011, revised 11 April 2011 accepted 27 May 2011) 